\section{Stored diaspores of Astronium urundeuva Fr. (M. Allemão) Engl. (Anacardiaceae) submitted to hydropriming}

\author{
Rafael Mateus Alves ${ }^{1^{*}}$ (iD, Monalisa Alves Diniz da Silva² ${ }^{2}$, Elania Freire da \\ Silva $^{3}$ iD, Robson José Rodrigues Alves ${ }^{2}$ D, Débora Purcina de Moura² ${ }^{(D}$, \\ Joyce Naiara da Silva ${ }^{4}$ iD
}

ABSTRACT: Seed deterioration is an irreversible process. However, techniques such as priming have been used after storage, in order to mitigate the harmful effects of aging. This study aimed to evaluate the physiological performance of $A$. urundeuva diaspores when stored and, subsequently, subjected to priming and drying, thus testing the hypothesis that hydropriming would mitigate deterioration. A completely randomized design was adopted, in a triple factorial scheme $2 \times 4 \times 4$, considering two environments (laboratory and refrigerated chamber), four storage times $(0,45,90$, and 180 days), and four hydration times $(0 \mathrm{~h} / \mathrm{dry}$ diaspores, $5 \mathrm{~h}, 14 \mathrm{~h} 30 \mathrm{~min}$, and $23 \mathrm{~h} 30 \mathrm{~min}$ ). Emergence, speed index, and the number of days to $50 \%$ emergence were assessed, as well as length and dry mass of both shoot and root systems. The storage of $A$. urundeuva diaspores for 180 days leads to a reduction in their physiological performance, regardless of the environment. The hydropriming times are not effective in attenuating the harmful effects of deterioration. Nevertheless, hydropriming for 23 h 30 min provides a faster seedling establishment.

Index terms: caatinga, aroeira of the hinterland, conservation, controlled hydration.

Diásporos armazenados de Astronium urundeuva Fr. (M. Allemão) Engl. (Anacardiaceae) submetidos a hidrocondicionamento

RESUMO: O processo de deterioração das sementes é tido como irreversível, mas técnicas como o priming são realizadas após o armazenamento visando atenuar os efeitos deletérios do envelhecimento. Objetivou-se avaliar o desempenho fisiológico de diásporos de $A$. urundeuva quando armazenados e, posteriormente, submetidos ao priming e à secagem, testando-se, assim, a hipótese de que o hidrocondicionamento funcionaria como um atenuador da deterioração. Adotou-se o delineamento inteiramente casualizado em esquema fatorial triplo $2 \times 4 \times 4$, sendo dois ambientes (laboratório e câmara refrigerada), quatro tempos de armazenamento (0, 45, 90 e 180 dias) e quatro períodos de hidratação ( 0 h/diásporos secos, 5 h, 14 h 30 min e 23 h 30 min). Avaliou-se emergência, índice de velocidade e número de dias para a ocorrência de $50 \%$ de emergência, assim como o comprimento e a massa seca da parte aérea e do sistema radicular. $\mathrm{O}$ armazenamento de diásporos de $A$. urundeuva por 180 dias acarreta a redução do desempenho fisiológico, independente do ambiente. Os períodos de hidrocondicionamento não são eficientes para atenuar os efeitos deletérios da deterioração. O hidrocondicionamento por $23 \mathrm{~h}$ e $30 \mathrm{~min}$ proporciona um estabelecimento mais rápido das plântulas.

Termos para indexação: caatinga, aroeira do sertão, conservação, hidratação controlada.

Journal of Seed Science, v.42, e202042026, 2020

http://dx.doi.org/10.1590/ 2317-1545v42236762

$*$ Corresponding author
E-mail: rafaelmateusalves@usp.br

Received: 4/17/2020.

Accepted: 6/14/2020.

${ }^{1}$ Departamento de Produção Vegetal, Escola Superior de

Agricultura Luiz de Queiroz, Universidade de São Paulo (ESALQUSP), 13418-900, Piracicaba - São Paulo, Brasil.

${ }^{2}$ Curso de Agronomia, Universidade Federal Rural de Pernambuco Unidade Acadêmica de Serra Talhada

(UAST-UFRPE), 56909-535, Serra Talhada - Pernambuco, Brasil.

${ }^{3}$ Programa de Pós-graduação em Produção Vegetal, (UAST-UFRPE), 56909-535, Serra Talhada Pernambuco, Brasil.

${ }^{4}$ Departamento de Agronomia, Universidade Federal da Paraíba - Centro de Ciências Agrárias (UFPBCCA), 58397-000, Areia - Paraíba, Brasil. 


\section{INTRODUCTION}

Astronium urundeuva (Allemão) Engl., Anacardiaceae, is native to northeastern Brazil, where it is popularly known as aroeira of the hinterland (aroeira-do-sertão). The plant bears pharmacological importance and has the potential for the restoration of degraded areas, but its survival is at considerable risk due to overexploitation (Centro Nacional de Conservação da Flora - CNCFlora, 2012).

The production of diaspores in perennial species can vary considerably from year to year (Smith and Samach, 2013), so that storage is used to regulate their availability (Bewley et al., 2013). The oleaginous diaspores of $A$. urundeuva do not display dormancy and have an orthodox storage behavior (Teófilo et al., 2004). They ought to be kept with some moisture content between 8 and 10\% (Guedes et al., 2012). The initial quality might remain the same or decline due to the deterioration, a process influenced by the moisture content of the diaspores, relative humidity of the air, and temperature (Marcos-Filho, 2015). Lipid peroxidation is deemed responsible for the membrane damage (Gaschler and Stockwell, 2017), which is pointed out as the primary characteristic of deterioration (Ratajczak et al., 2019).

In a natural environment, $A$. urundeuva diaspores quickly lose their viability and vigor after storage (Caldeira and Perez, 2008). This phenomenon happens because the diaspores are rich in lipids (Guedes et al., 2012), and it tends to be more intense in surroundings with high humidity (Mira et al., 2015). A widespread consensus state that, although it can be preserved, seed quality cannot be enhanced during storage (Marcos-Filho, 2015; Mishra et al., 2016). In turn, priming after storage has been used as an alternative for minimizing detrimental effects resulting from deterioration.

Priming encompasses pre-germinative treatments that benefit seed germination and the subsequent seedling emergence - this set of techniques is internationally known as "seed enhancements". Its principle is to supply the seeds with water under controlled conditions, thus stimulating their metabolism during phases I and II of the imbibition, without causing the protrusion of the primary root (Bewley et al., 2013). This allows the membrane system to restructure itself, minimizing the excessive release of exudates (Marcos-Filho, 2015). This method can induce mechanisms of both protection and repair in seeds, making them capable of tolerating future stresses (Kubala et al., 2015), and favoring faster germination and the proper establishment of the specimens (Lopes et al., 2019).

Priming can boost germination and improve seedling performance, especially in arid and semi-arid regions, characterized by irregular rainfall (Finch-Savage et al., 2004). In this context, Meiado et al. (2012) reported that seeds of species native to the Brazilian Caatinga could only be sown when water is available in the soil (from January to May). In this case, priming after storage could contribute to extending the sowing period. Similar cases with successful results include deteriorated seeds of Onobrychis crista-galli (L.) Lam. (Kavandi et al., 2018), which were stored in a germplasm bank, and were recovered by using osmopriming. In another research, seeds of Trema orientalis Linn. Blume benefited from a hydration-dehydration process, regardless of whether it were applied before or after storage (Yuniarti et al., 2019).

On that account, this work aimed to assess the physiological performance of diaspores of $A$. urundeuva when stored, and subsequently subjected to priming and drying. The hypothesis is that hydropriming works by attenuating the deterioration.

\section{MATERIAL AND METHODS}

Diaspores of A. urundeuva were provided by the Center for Ecology and Environment Monitoring (Núcleo de Ecologia e Monitoramento Ambiental, NEMA), from the Federal University of Vale do São Francisco (Universidade Federal do Vale do São Francisco, UNIVASF), in Petrolina, state of Pernambuco (PE), Brazil. They were harvested from the parent trees in late September and early October 2018, in the city of Salgueiro (PE) (803'28' S, 39 $05^{\prime} 45^{\prime \prime}$ W, $511 \mathrm{~m}$ altitude).

Between October and November 2018, the diaspores were manually processed with the aid of a sieve. Next, they were packed in transparent plastic bags and kept in ambient condition until mid-January 2019, when the experiment initiated.

Storage: the physiological quality of the diaspores was first appraised before they were stored under the specific experimental conditions (time zero). The diaspores stowed in $250 \mathrm{~mL}$ plastic bottles were kept either in laboratory 
conditions $\left(32.2 \pm 2{ }^{\circ} \mathrm{C}, 45.67 \% \mathrm{RH}\right)$ or inside a refrigerated chamber $\left(20.8 \pm 2{ }^{\circ} \mathrm{C}, 56.16 \% \mathrm{RH}\right)$, for $0,45,90$, and 180 days. At the end of each period, the moisture content was assessed by the oven method at $105 \pm 3{ }^{\circ} \mathrm{C}$ for 24 hours. The results were expressed in percentage (Brasil, 2009).

Hydropriming: after storage, the diaspores were subjected to four hydration times, which were established according to an imbibition curve obtained previously. Therefore, these times considered the absence of hydropriming (0h/dry diaspores), and the hydration periods corresponding to $1 / 2$ of phase I (5 h), $1 / 4$ of phase II (14 h $30 \mathrm{~min}$ ), and $3 / 4$ of phase II (23 h $30 \mathrm{~min}$ ) of the three-phase imbibition process (Lima et al., 2018). For hydropriming, the diaspores were weighed and then laid onto two blotting-paper sheets, moistened with $15 \mathrm{~mL}$ of distilled water (predetermined value). Then, they were placed inside acrylic gerboxes, at a constant temperature of $25 \pm 2{ }^{\circ} \mathrm{C}$, in the presence of light. After each hydropriming period, two replications with 25 diaspores each had their moisture content analyzed (Brasil, 2009). At the same time, the remaining diaspores were oven-dried $\left(30 \pm 2{ }^{\circ} \mathrm{C}\right)$, and had their weight monitored every 30 minutes, until reaching approximately a 15\% moisture content (Ataíde et al., 2016). Ultimately, seedling emergence and performance were also evaluated.

Emergence: four replications of 25 diaspores from each treatment were sown in 200-cell plastic trays (18 $\mathrm{cm}^{3}$ per cell), filled with sterilized sand. The evaluation was carried out daily by counting the normal seedlings (germination criterion). The tests of emergence speed index (Maguire, 1962) and the number of days to 50\% emergence (T50) (Farooq et al., 2005) were carried out simultaneously.

Seedling length: once the emergence had stabilized ten days past sowing, the seedlings were measured for shoot length (from the neck to apical meristem) and root system length (from the neck to the extremity of the primary root). A graduated ruler was used and the results were expressed in $\mathrm{cm}$.seedling ${ }^{-1}$.

Dry mass of seedlings: the shoot and root system of the normal seedlings of each replication were packed in properly identified Kraft paper bags. They were dried in a forced-circulation oven set at $80^{\circ} \mathrm{C}$ for 24 hours. After that, they were weighed on an analytical balance with precision to three decimal places, and the results were expressed in g.seedling ${ }^{-1}$.

Experimental design: the study complied with a completely randomized design, in a triple factorial scheme $(2 \times 4 \times 4)$, with two environments (laboratory and refrigerated chamber), four storage times (0, 45, 90, and 180 days), and four hydration times after storage ( $0 \mathrm{~h} / \mathrm{dry}$ diaspores, $5 \mathrm{~h}, 14 \mathrm{~h} 30 \mathrm{~min}$, and $23 \mathrm{~h} 30 \mathrm{~min}$ ).

The analysis of variance employed the $F$ test $(p \leq 0.05)$, and, once verified a significant interaction, the quantitative factors were subjected to regression analysis. That not being the case, the averages of the qualitative factors were compared by the Tukey test $(p \leq 0.05)$. All statistical analyzes were handled by the software SISVAR v.5.6 (Ferreira, 2011), and the graphs were built with the software Sigma Plot 10.0.

\section{RESULTS AND DISCUSSION}

Neither the emergence nor the performance of $A$. urundeuva seedlings was affected by the environment, storage time, or hydropriming. Thus, there was no significant triple interaction, regardless of the variable (Table 1). On the contrary, the double interaction between the environment and storage period was significant - except for the number of days to $50 \%$ emergence (T50). When considered individually, the environment, storage time, and hydropriming factors differed significantly from T50. Lastly, hydropriming delivered a significant difference as for the lengths of the shoot and root system.

The diaspores had an average initial moisture content of $10.2 \%$. After being stored for 180 days, either under uncontrolled laboratory conditions or inside the refrigerated chamber, they achieved $11.2 \%$ and $11.9 \%$, respectively (Table 2). Similar results were found by Guedes et al. (2012), who observed that the moisture content of $A$. urundeuva diaspores increased throughout storage in all environments tested - but the best conservation result was attained between 8 and $10 \%$.

The more the diaspore was exposed to the moistened substrate, the higher their average moisture content, regardless of the storage conditions (Table 2). After the hydroprimed diaspores were dried, their average moisture content was about 15\% (Table 2). According to Ataíde et al. (2016), this moisture level favored the germinative capacity 
of seeds of Dalbergia nigra (Vell.) Fr. All. Ex Benth (Fabaceae). On the other hand, higher or lower values proved to be harmful to that species germination.

Regarding the interaction between the environment and time of storage on the emergence (Figure 1) and emergence speed index (Figure 2), a decrease trend was noticed over time, with the highest values of these attributes being observed prior to storage (Figures 1 and 2). Even so, the diaspores kept in the refrigerated chamber provided the highest emergence speed indices (Figure 2). Guedes et al. (2012) considered that the decline in the emergence speed was the first vigor alteration noticeable in diaspores of $A$. urundeuva stored for 240 days.

Table 1. Summary of the analysis of variance of the means of the initial development parameters of Astronium urundeuva seedlings grown from diaspores subjected to the storage, hydropriming, and drying.

\begin{tabular}{|c|c|c|c|c|c|c|c|c|}
\hline \multirow{2}{*}{ Source of variation } & \multirow[b]{2}{*}{ DF } & \multicolumn{7}{|c|}{ Mean Square } \\
\hline & & $E$ & ESI & T50 & LS & LRS & DMS & DMRS \\
\hline ST & 3 & $13194.7^{* *}$ & $36.3^{* *}$ & $8.65^{* *}$ & $2.59 * *$ & $1.79 * *$ & $0.0002^{\mathrm{ns}}$ & $0.001 * *$ \\
\hline SE & 1 & $887.2^{*}$ & $2.85^{*}$ & $3.38^{*}$ & $1.36 * *$ & $0.02^{\text {ns }}$ & $0.003^{* *}$ & $0.003^{* *}$ \\
\hline HP & 3 & $459.0^{\text {ns }}$ & $1.23^{\text {ns }}$ & $2.94 *$ & $0.35 *$ & $0.91^{* *}$ & $0.0001^{\mathrm{ns}}$ & $0.00008^{\mathrm{ns}}$ \\
\hline ST $\times$ SE $\times$ HP & 9 & $48.6^{\mathrm{ns}}$ & $0.14^{\text {ns }}$ & $0.66^{\mathrm{ns}}$ & $0.15^{\mathrm{ns}}$ & $0.12^{\mathrm{ns}}$ & $0.00007^{\mathrm{ns}}$ & $0.0001^{\text {ns }}$ \\
\hline ST $\times \mathrm{HP}$ & 3 & $501.7^{*}$ & $1.83^{*}$ & $1.22^{\mathrm{ns}}$ & $0.55^{* *}$ & $0.7^{* *}$ & $0.005^{* *}$ & $0.002 * *$ \\
\hline ST $\times \mathrm{HP}$ & 9 & $152.9^{\text {ns }}$ & $0.41^{\text {ns }}$ & $0.88^{\text {ns }}$ & $0.08^{\text {ns }}$ & $0.04^{\text {ns }}$ & $0.0001^{\text {ns }}$ & $0.00008^{\text {ns }}$ \\
\hline SE $\times$ HP & 3 & $3.69^{\text {ns }}$ & $0.06^{\text {ns }}$ & $0.55^{\mathrm{ns}}$ & $0.08^{\mathrm{ns}}$ & $0.12^{\text {ns }}$ & $0.0001^{\mathrm{ns}}$ & $0.00009^{\text {ns }}$ \\
\hline Total & 127 & - & - & - & - & - & - & - \\
\hline CV (\%) & & 30.9 & 31.8 & 18.26 & 12.5 & 15.1 & 29.4 & 28.4 \\
\hline
\end{tabular}

ns: non-significant; ${ }^{* *},{ }^{*}$ : significant at $1 \%$ and $5 \%$ probability levels, respectively, according to the $\mathrm{F}$ test; $\mathrm{E}-\mathrm{emergence}(\%)$; ESI emergence speed index; T50 - number of days to 50\% emergence; LS - length of the shoot (cm.seedling ${ }^{-1}$ ); LRS - length of the root system (cm.seedling ${ }^{-1}$ ); DMS - dry mass of the shoot (g.seedling $\left.{ }^{-1}\right)$; DMRS - dry mass of the root system (g.seedling ${ }^{-1}$ ); ST - storage time; SE - storage environment; HP - hydropriming.

Table 2. Moisture content of Astronium urundeuva diaspores before and after hydropriming performed subsequent to storage and drying.

\begin{tabular}{|c|c|c|c|c|c|c|c|c|}
\hline \multirow{4}{*}{ Storage environment } & \multirow{4}{*}{$\begin{array}{l}\text { Storage time } \\
\text { (days) }\end{array}$} & \multicolumn{7}{|c|}{ Moisture content (\%) } \\
\hline & & \multicolumn{4}{|c|}{ Hydropriming } & \multirow{2}{*}{\multicolumn{3}{|c|}{ After drying }} \\
\hline & & Before & & After & & & & \\
\hline & & $\mathrm{T} 1$ & $\mathrm{~T} 2$ & T3 & $\mathrm{T} 4$ & T2' & T3' & $\mathrm{T}^{\prime}$ \\
\hline \multirow{4}{*}{ A } & 0 & 10.2 & 33.9 & 40.6 & 54.6 & 13.8 & 14.7 & 14.5 \\
\hline & 45 & 11.8 & 37.8 & 52.7 & 56.6 & 15.6 & 15.5 & 16.54 \\
\hline & 90 & 11.5 & 34.4 & 53.7 & 58.3 & 13.8 & 14.9 & 17.24 \\
\hline & 180 & 11.6 & 36.6 & 48.3 & 51.2 & 15.82 & 14.6 & 18.18 \\
\hline \multirow{4}{*}{ B } & 0 & 10.2 & 33.9 & 40.6 & 54.6 & 13.8 & 14.7 & 14.5 \\
\hline & 45 & 12.4 & 40.6 & 54.1 & 57.8 & 15.3 & 16.5 & 16.5 \\
\hline & 90 & 12.1 & 43.4 & 56.5 & 59.7 & 14.5 & 16.4 & 15.7 \\
\hline & 180 & 12.8 & 44.7 & 50.6 & 56.9 & 15.6 & 15.9 & 16.6 \\
\hline
\end{tabular}

A: environment without temperature or relative humidity control; B: refrigerated chamber. Seeds without hydropriming (T1); seeds with hydropriming based on $1 / 2$ of phase I (T2 - $5 \mathrm{~h}$ ), $1 / 4$ of phase II (T3 - $14 \mathrm{~h} 30 \mathrm{~min}$ ), and $3 / 4$ of phase II (T4 - $23 \mathrm{~h} 30 \mathrm{~min}$ ) of the three-phase imbibition process. 


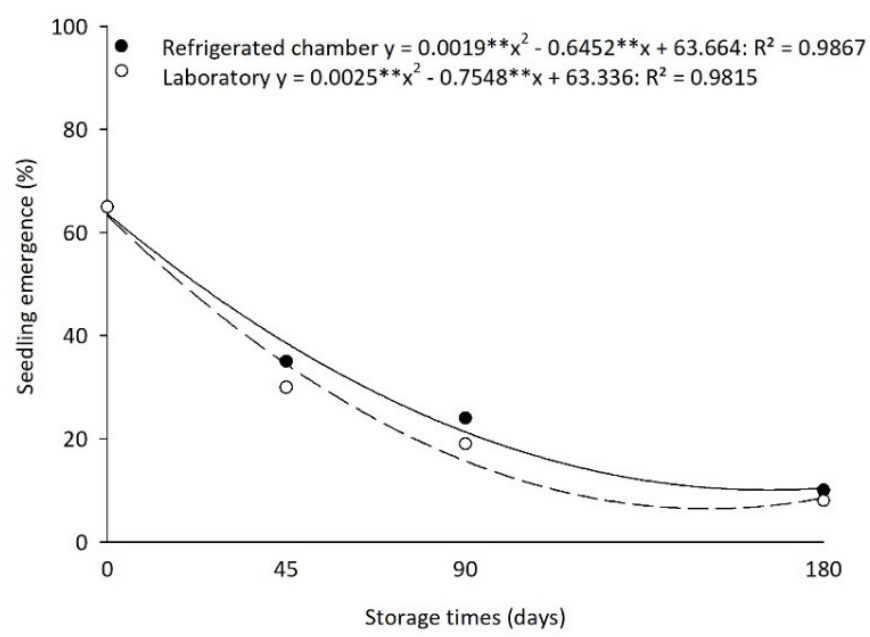

Figure 1. Effect of the times and environments of storage on the emergence of Astronium urundeuva normal seedlings.

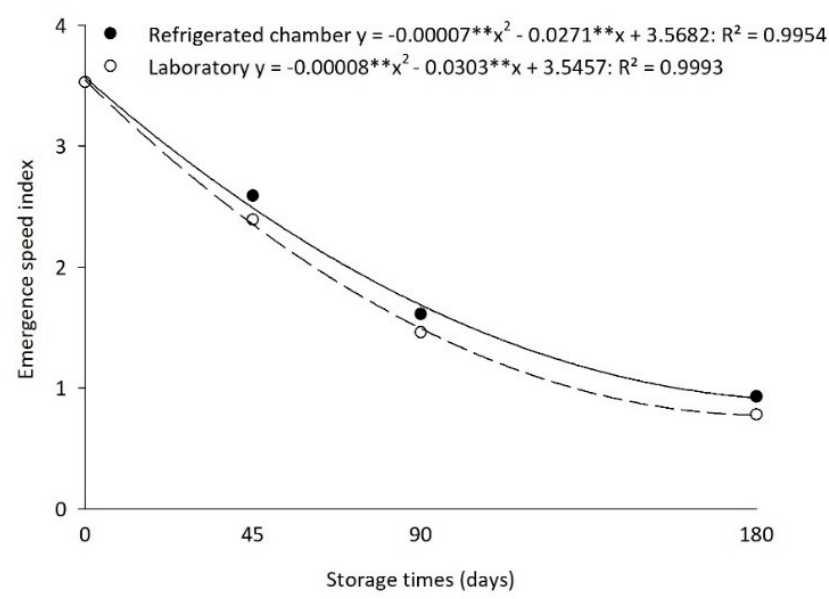

Figure 2. Effect of the times and environments of storage on the emergence speed index of Astronium urundeuva normal seedlings.

The physiological quality of the diaspores stored under uncontrolled environmental conditions was lower, which corroborates with the findings of Caldeira and Perez (2008). This possibly happens because the average temperature over the 180 days of storage $\left(32.2 \pm 2^{\circ} \mathrm{C}\right)$ accelerated the metabolism and, consequently, intensified the respiration process.

Vigor loss in A. urundeuva diaspores is likely the result of their chemical composition. Despite having an orthodox behavior, their high oil content causes their germination power to reduce (Teófilo et al., 2004; Guedes et al., 2012), as lipids have less chemical stability than starches (Balešević-Tubić et al., 2010). Thus, in circumstances where the air temperature is low, as in a refrigerated chamber $\left(20.8 \pm 2{ }^{\circ} \mathrm{C}\right)$, the diaspore metabolism tends to decelerate, resulting in the decrease of physiological activities and fewer losses due to respiration and lipid peroxidation (Marcos-Filho, 2015).

The mobilization of lipid reserves is paramount during the post-germination until the seedlings properly establish and become autotrophic. However, the lipid oxidation compromises this process (Hooks et al., 2010). Storage at low temperatures proved to be an efficient technique to prevent the mobilization of seed reserve compounds in Amburana cearenses (Allemão) AC Sm. (Fabaceae) (Araujo et al., 2017). It also kept the viability of $A$. urundeuva diaspores for up to four months (Oliveira et al., 2018) and guaranteed good seedling emergence of Adenanthera pavonina L. (Fabaceae) (Gugé et al., 2019).

The diaspores subjected to hydropriming for $23 \mathrm{~h} 30 \mathrm{~min}$ took fewer days to reach a $50 \%$ emergence (T50) than those 
of the control treatment (dry diaspores) (Figure 3). Consequently, priming provided a positive acceleration in metabolism, which might represent an ecological advantage in restoration programs for the Brazilian Caatinga. In similar studies, hydration also favored the emergence of Jatropha curcas L. (Euphorbiaceae) (Braga et al., 2012) and D. nigra. In those cases, after being subjected to priming, the seeds became physiologically closer to the early phase III of imbibition, which led to the stimulation of the primary root protrusion (Ataíde et al., 2016). In turn, discontinuous hydration significantly influenced the number of days to $50 \%$ germination of seeds of Mimosa tenuiflora (Willd.) Poir. (Fabaceae) (Lima and Meiado, 2018).

With regards to the storage times, there was an increasing tendency in the number of days to $50 \%$ of emergence, with the storage for 180 days demanding the longest (Figure 4A). As for the storage environments, the diaspores kept inside the refrigerated chamber required fewer days to deliver a $50 \%$ emergence than those stored in the laboratory environment (Figure 4B).

The length (Figures 5A and 5B) and dry mass (Figures 6A and 6B) of the shoot and root systems showed a statistical

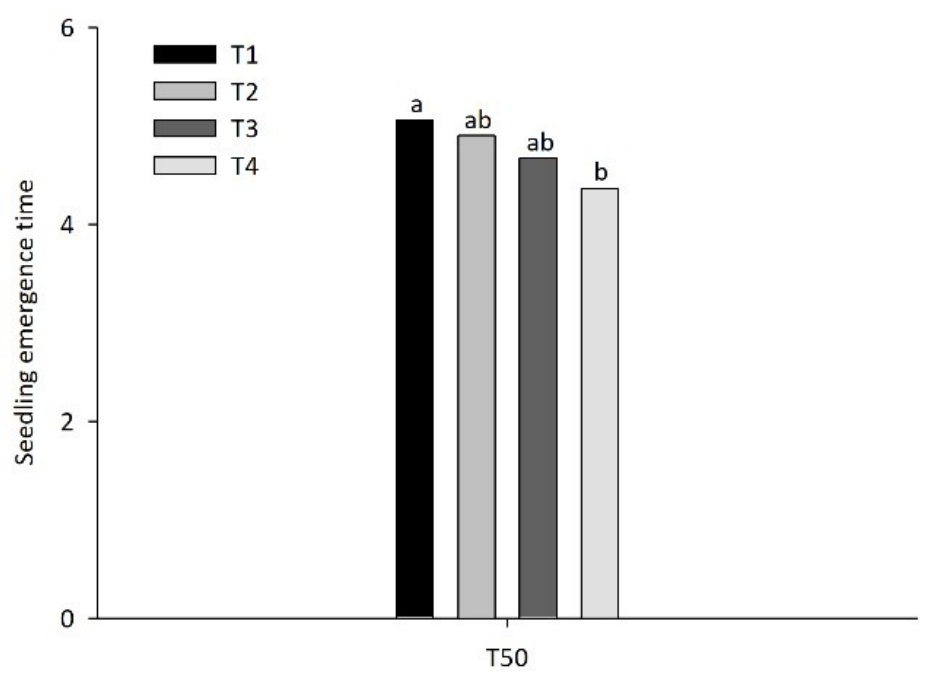

Means followed by the same letter do not differ, according to Tukey's test ( $p \leq 0.05)$. Seeds without hydropriming (T1); seeds with hydropriming based on $1 / 2$ of phase I (T2 $-5 \mathrm{~h}$ ), $1 / 4$ of phase II (T3-14 h $30 \mathrm{~min}$ ), and $3 / 4$ of phase II (T4 - $23 \mathrm{~h} 30 \mathrm{~min}$ ) of the three-phase imbibition process.

Figure 3. Effect of hydropriming on the number of days to $50 \%$ emergence of Astronium urundeuva normal seedlings.

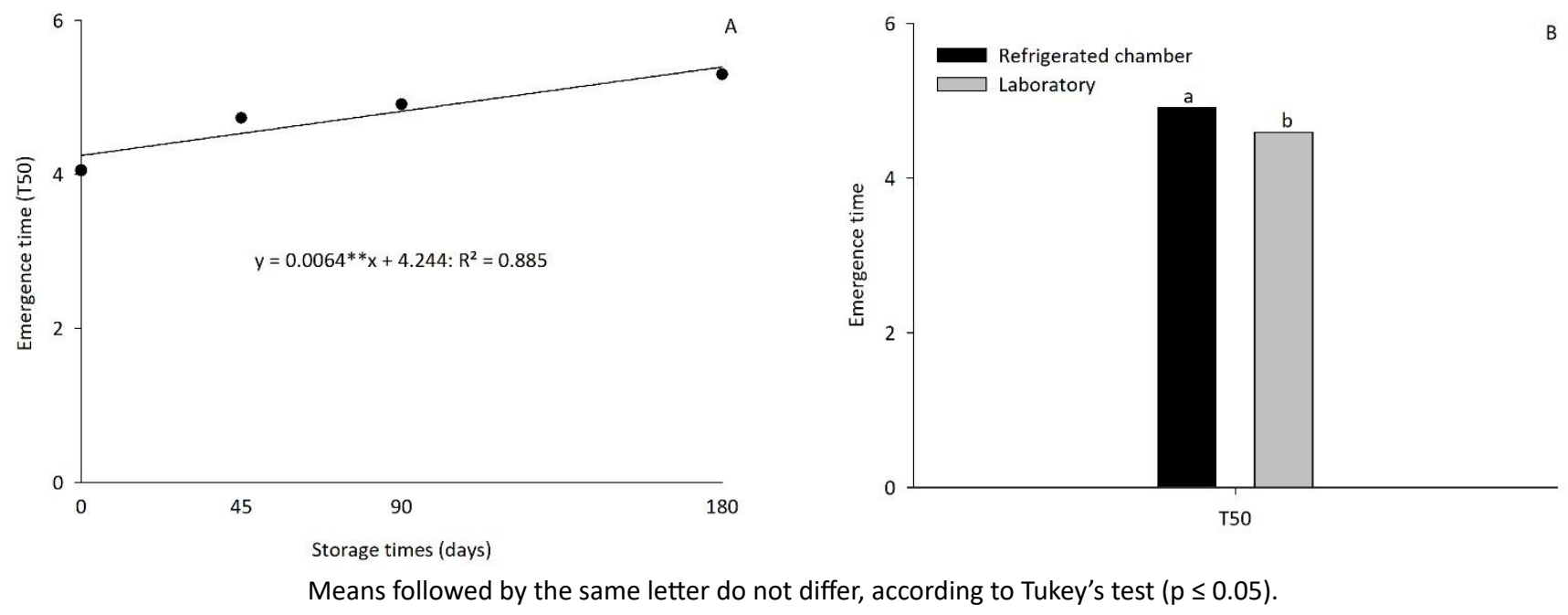

Figure 4. Effect of the times (A) and environments (B) of storage on the number of days to $50 \%$ emergence of Astronium urundeuva normal seedlings. 
difference for the interaction between environments and storage times. Diaspores stored in the refrigerated chamber produced more vigorous seedlings, possibly due to the lower intensity of the respiratory process, which delayed the consumption of reserve substances. Over the storage periods, there was a decline in the variables mentioned above, especially by 180 days (Figures $5 \mathrm{~A}, 5 \mathrm{~B}, 6 \mathrm{~A}$, and $6 \mathrm{~B}$ ). The interference in the translocation of reserves from either the endosperm or cotyledons to the embryonic axis growth (Amaro et al., 2015) reflects in a reduction of the length and dry mass of both shoot and root system.

Regardless of the duration, hydropriming did not elongate the shoot or root system, in contrast to the lack thereof. In turn, priming for $23 \mathrm{~h} 30 \mathrm{~min}$ (T4) favored the growth of the shoot, in contrast to the procedure conducted for $5 \mathrm{~h}$ (T2), and also of the root system, in comparison to the periods of $5 \mathrm{~h}$ and $14 \mathrm{~h} 30 \mathrm{~min}$ of hydration (Figure 7). The discontinuous hydration incremented the development of the A. urundeuva seedlings (Hora and Meiado, 2016). Cycles of hydration and dehydration in seeds of Antirrhinum spp., Dahlia spp., Impatiens walleriana spp., Salvia splendens Sellow ex Roem. \& Schult. (Lamiaceae), and Zinnia spp. provided seedlings with high amounts of biomass (Ozden et al., 2017).

The minimum moisture content to trigger the germination process depends on the chemical composition and permeability of the integument (Bradford, 1986). The diaspores of $A$. urundeuva are oleaginous (Teófilo et al., 2004;
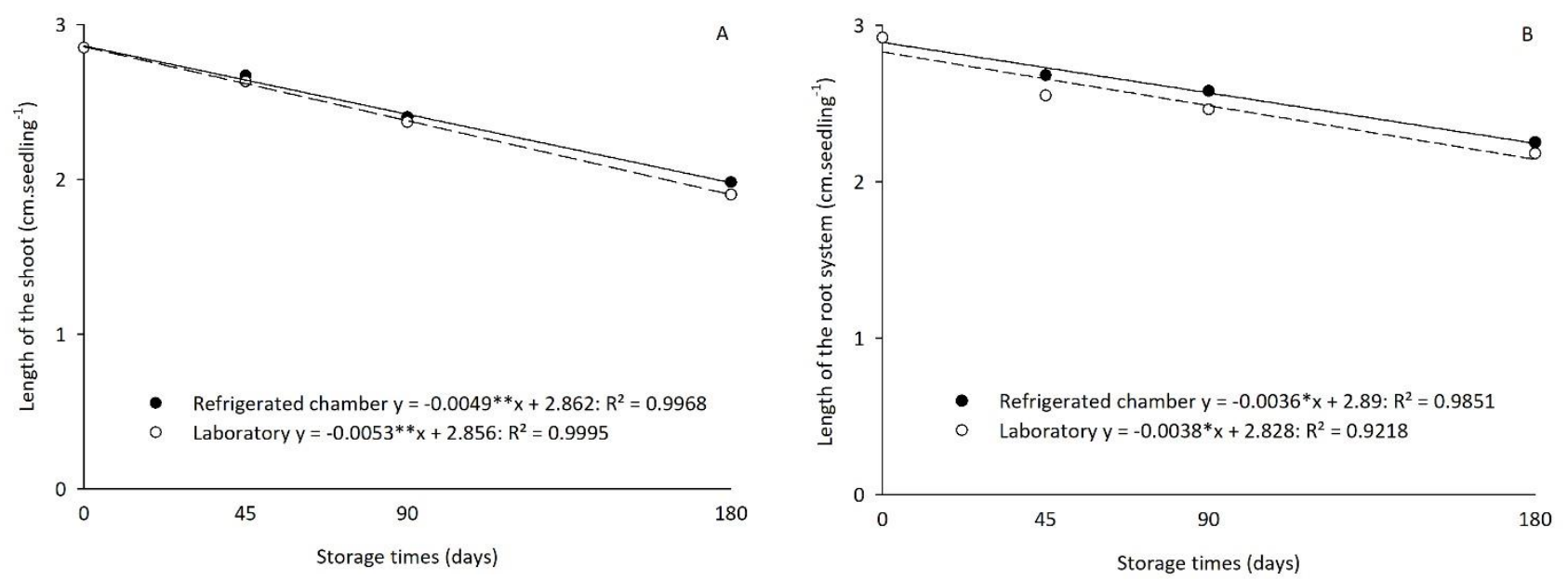

Figure 5. Effect of the times and environments of storage on the length of the shoot (A) and root system (B) of Astronium urundeuva normal seedlings.
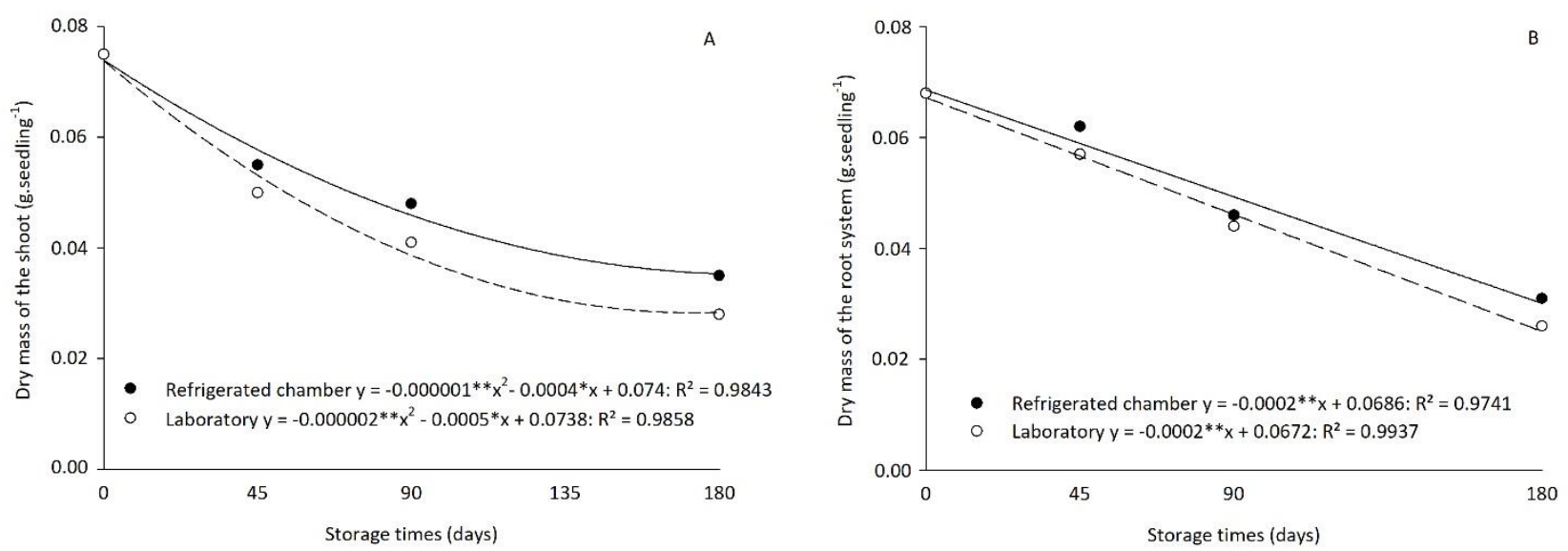

Figure 6. Effect of the times and environments of storage on the dry mass of the shoot (A) and root system (B) of Astronium urundeuva normal seedlings. 


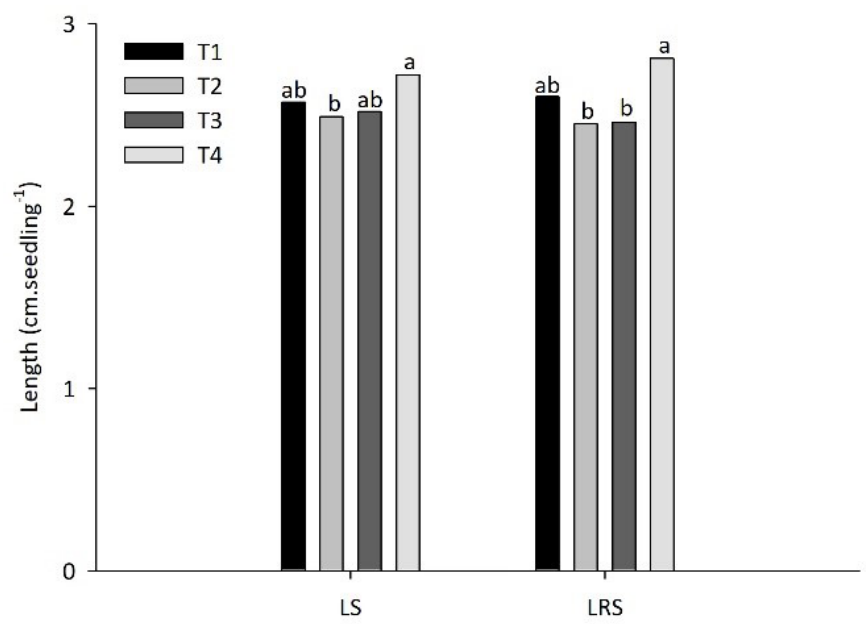

\begin{abstract}
Means followed by the same letter do not differ, according to Tukey's test ( $p \leq 0.05)$. Seeds without hydropriming (T1); seeds with hydropriming based on $1 / 2$ of phase I (T2 - 5 h), $1 / 4$ of phase II (T3-14 h $30 \mathrm{~min}$ ), and $3 / 4$ of phase II (T4 - $23 \mathrm{~h} 30 \mathrm{~min}$ ) of the three-phase imbibition process.
\end{abstract}

Figure 7. Effect of hydropriming on the length of the shoot (LS) and root system (LRS) of Astronium urundeuva normal seedlings.

Guedes et al., 2012), with a resinous mesocarp and a membranous integument (Almeida et al., 1998). Therefore, these characteristics tend to limit a prompter response to priming, especially when compared to starchy diaspores bearing a non-waxy permeable integument.

Employing hydropriming for mitigating the effect of the deterioration process during storage still requires further research, as the final results are deeply influenced by aspects such as the genotype, climatic conditions, pre- and post-harvest procedures, duration of hydration, drying processes, and the number of hydration-drying cycles. Climate changes also require knowledge relevant to methods that can be applied to stored diaspores to increase the survival of the seedlings in the field.

\title{
CONCLUSIONS
}

Storing $A$. urundeuva diaspores for 180 days reduces their physiological performance, regardless of the storage environment.

Hydropriming, with a discontinuous hydration cycle after the storage, regardless of its duration, is not efficient in mitigating the deleterious effects of the deterioration process on $A$. urundeuva diaspores.

A. urundeuva diaspores subjected to hydropriming for $23 \mathrm{~h} 30 \mathrm{~min}$ post storage, regardless of the environment and storage time, deliver a faster seedling establishment.

\section{ACKNOWLEDGEMENTS}

The authors express their gratitude to the Center for Ecology and Environmental Monitoring (Núcleo de Ecologia e Monitoramento Ambiental, NEMA/UNIVASF), the Project for the Integration of the São Francisco River with the Hydrographic Basins of the Northern Northeast (PISF), and the Ministry of Regional Development (MDR), for providing the diaspores of $A$. urundeuva. Also, to the Federal Rural University of Pernambuco (Universidade Federal Rural de Pernambuco, UFRPE), Serra Talhada Academic Unit (Unidade Acadêmica de Serra Talhada, UAST), and the Postgraduate Program in Plant Production (Programa de Pós-Graduação em Produção Vegetal, UFRPE/UAST), for making their infrastructure available for the execution of this work. To the National Council for Scientific and Technological Development (CNPq) for granting an academic scholarship to the first author. 


\section{REFERENCES}

ALMEIDA, S.P.; PROENÇA, C.E.B.; SANO, S.M.; RIBEIRO, J.F. Cerrado: espécies vegetais úteis. Planaltina: EMBRAPA-CPAC, 1998. 464p.

AMARO, H.T.R.; DAVID, A.M.S.S.; ASSIS, M.O.; RODRIGUES, B.R.A.; CANGUSSÚ, L.V.S.; OLIVEIRA, M.B. Testes de vigor para avaliação da qualidade fisiológica de sementes de feijoeiro. Revista de Ciências Agrárias, v.38, n.3, p.383-389, 2015. http://www.scielo.mec. pt/scielo.php?script=sci_arttext\&pid=S0871-018X2015000300013.

ARAUJO, M.N.; FERRAZ, M.; AMÉRICO, F.K.A.; SILVA, F.F.S.; DANTAS, B.F.; CRUZ, C.R.P. Seed quality of Amburana cearensis (Allemão) A.C. Sm. (Fabaceae) is influenced by storage condition. Journal of Seed Science, v.39, n.4, p.401-409, 2017. http://dx.doi. org/10.1590/2317-1545v39n4179328.

ATAÍDE, G.M.; LIMA, E.E.B.; GONÇALVES, J.F.C.; GUIMARÃES, V.M.; FLORES, A.V. Alterações fisiológicas durante a hidratação de sementes de Dalbergia nigra ((Vell.) Fr. All. ex Benth.). Ciência Florestal, v.26, n.2, p.615-625, 2016. https://doi. org/10.5902/1980509822761.

BALEŠEVIĆ-TUBIĆ, S.; TAÍC, M.; DORDEVIC, V.; NIKOLIC, Z.; DUKIC, V. Seed viability of oil crops depending on storage conditions. Helia, v.33, n.52, p.153-159. 2010. http://dx.doi.org/10.2298/hel1052153b.

BEWLEY, J.D.; BRADFORD, J.D.; HILHORST, H.; NONOGAKI, H. Longevity, storage, and deterioration. In: BEWLEY, J.D.; BRADFORD, K.J.; HILLHORST, H.W.M.; NONOGAKI, H. (Ed.) Seeds: Physiology of development, germination and dormancy. Springer. p. 341-376, 2013. https://doi.org/10.1007/978-1-4614-4693-4_8.

BRADFORD, K.J. Manipulation of seed water relations via osmotic priming to improve germination under stress conditions. HortScience, v.21, n.5, p.1105-1112, 1986.

BRAGA, N.S.; MORAIS, C.S.B.; ROSSETTO, C.A.V. Hidratação controlada de sementes de pinhão manso. Revista Ciência Agronômica, v.43, n.3, p.589-597, 2012. http://www.scielo.br/pdf/rca/v43n3/a23v43n3.pdf.

BRASIL. Ministério da Agricultura, Pecuária e Abastecimento. Regras para análise de sementes. Ministério da Agricultura, Pecuária e Abastecimento. Secretaria de Defesa Agropecuária. Brasília: MAPA/ACS, 2009. 395p. https://www.abrates.org.br/files/regras_ analise_de_sementes.pdf.

CALDEIRA, S.F.; PEREZ, S.C.J.G.A. Qualidade de diásporos de Myracrodruon urundeuva Fr. All. armazenados sob diferentes condições. Revista Brasileira de Sementes, v.30, n.3, p.185-94, 2008. https://doi.org/10.1590/S0101-31222008000300025

CNCFlora. Myracrodruon urundeuva in Lista Vermelha da flora brasileira versão 2012.2, Centro Nacional de Conservação da Flora. http://cncflora.jbrj.gov.br/portal/pt-br/profile/Myracrodruonurundeuva.

FAROOQ, M.; BASRA, S.M.A.; AHMAD, N.; HAFEEZ, K. Thermal hardening: a new seed vigor enhancement tool in rice. Journal of Integrative Plant Biology, v.47, n.2, p.187-193, 2005. https://doi.org/10.1111/j.1744-7909.2005.00031.x.

FERREIRA, D.F. Sisvar: a computer statistical analysis system. Ciência e Agrotecnologia, v.35, n.6, p.1039-1042, 2011. https://doi. org/10.1590/S1413-70542011000600001.

FINCH-SAVAGE, W.E.; DENT, K.C.; CLARK, L.J. Soak conditions and temperature following sowing influence the response of maize (Zea mays L.) seeds to on-farm priming (Pre-Sowing Seed Soak). Field Crops Research, v.90, n.1-2, p.361-374, 2004. https://doi. org/10.1016/j.fcr.2004.04.006.

GASCHLER, M.M.; STOCKWELL, B.R. Lipid peroxidation in cell death. Biochemical and Biophysical Research Communications, v.482, n.3, p.419-425, 2017. https://doi.org/10.1016/j.bbrc.2016.10.086.

GUEDES, R.S.; ALVES, E.U.; BRUNO, R.L.A.; GONÇALVES, E.P.; COSTA, E.G.; MEDEIROS, M.S. Armazenamento de sementes de Myracrodruon urundeuva Fr. All. em diferentes embalagens e ambientes. Revista Brasileira de Plantas Medicinais, v.14, n.1, p.6875, 2012. https://doi.org/10.1590/S1516-05722012000100010.

GUGÉ, L.M.A.; GUGÉ, R.M.A.; COELHO, R.S.; NASCIMENTO, F.M.; CASTRO FILHO, M.N. Avaliação de técnicas de armazenamento de sementes de tento-carolina (Adenanthera pavonina L.) em função de diferentes tipos de embalagens e ambientes. Biodiversidade, n.18, v.3, p.126-135, 2019. http://periodicoscientificos.ufmt.br/ojs/index.php/biodiversidade/article/view/9411/6488.

HOOKS, M.A.; ALLEN, E.; WATTIS, J.A.D. Modelling the peroxisomal carbon leak during lipid mobilization in Arabidopsis. Biochemical Society Transactions, v.38, n.5, p.1230-1233, 2010. https://doi.org/10.1042/BST0381230. 
HORA, I.S.; MEIADO, M.V. A hidratação descontínua em sementes favorece a produção de mudas de Myracrodruon urundeuva Allemão (Anacardiaceae)?. Agroforestalis News, v.1, n.1, p.20-24, 2016. https://seer.ufs.br/index.php/AGRO/article/view/5362.

KAVANDI, A.; JAFARI, A.A.; JAFARZADEH, M. Effect of seed priming on enhancement of seed germination and seedling growth of annual sainfoin (Onobrychis crista-galli (L.) Lam.) in medium and long-term collections of gene bank. Journal of Rangeland Science, v.8, n.2, p.117-128, 2018. http://www.rangeland.ir/article_540632.html.

KUBALA, S.; WOJTYLA, L.; QUINET, M.; LECHOWSKA, K.; LUTTS, S.; GARNCZARSKA, M. Enhanced expression of the proline synthesis gene P5CSA in relation to seed osmopriming improvement of Brassica napus germination under salinity stress. Journal of Plant Physiology, v.183, n.1, p.1-12, 2015. https://doi.org/10.1016/j.jplph.2015.04.009.

LIMA, A.T.; CUNHA, P.H.J.; DANTAS, B.F.; MEIADO, M.V. Does discontinuous hydration of Senna spectabilis (DC.) H.S. Irwin \& Barneby var. excelsa (Schrad.) H.S. Irwin \& Barneby (Fabaceae) seeds confer tolerance to water stress during seed germination? Journal of Seed Science, v.40, n.1, p.036-043, 2018. http://dx.doi.org/10.1590/2317-1545v40n1182838.

LIMA, A.T.; MEIADO, M.V. Effect of hydration and dehydration cycles on Mimosa tenuiflora seeds during germination and initial development. South African Journal of Botany, v.116, p.164-167, 2018. https://doi.org/10.1016/j.sajb.2018.03.017.

LOPES, C. A.; CARVALHO, M. L. M.; GUIMARÃES, R. M.; OLIVEIRA, A. M. S.; ANDRADE, D. B. Sodium hypochlorite in the priming of tobacco seeds. Journal of Seed Science, v.41, n.1, p.108-111, 2019. http://dx.doi.org/10.1590/2317-1545v41n1211719

MAGUIRE, J.B. Speed of germination-aid in selection and evaluation for seedling emergence vigor. Crop Science, v.2, n.2, p.176-177, 1962. http://dx.doi.org/10.2135/cropsci1962.0011183X000200020033x.

MARCOS-FILHO, J. Fisiologia de sementes de plantas cultivadas. Londrina: ABRATES, 2015. 659p.

MEIADO, M.V.; SILVA, F.F.S.; BARBOSA, D.C.A.; SIQUEIRA-FILHO, J.A. Diaspore of the Caatinga: A Review. In: SIQUEIRA FILHO, J.A. (Ed.). Flora of the Caatingas of the São Francisco River: Natural History and Conservation. Rio de Janeiro: Andrea Jakobsson Estúdio Editorial, p.306-365, 2012.

MIRA, S.; ESTRELLES, E.; GONZÁLEZ-BENITO, M.E. Effect of water content and temperature on seed longevity of seven Brassicaceae species after five years of storage. Plant Biology Journal, v.17, p.153-162, 2015. https://doi.org/10.1111/plb.12183.

MISHRA, P.K.; PAROHA, S.; MISHRA, P. A review on effects of storage on the quality and viability characteristics of major oilseeds. International Journal os Current Research and Academic Review, v.4, n.1, p.108-121, 2016. http://dx.doi.org/10.20546/ ijcrar.2016.401.010.

OLIVEIRA, F.T.G.; VITÓRIA, R.Z.; POSSE, S.C.P.; ARANTES, S.D.; SCHMILDT, O.; VIANA, A.; MALIKOUSKI, R.G.; BARROS, B.L.A. Qualidade fisiológica de sementes de aroeira em função das condições de armazenamento. Nucleus, v.15, n.2, p.567-574, 2018. https:// biblioteca.incaper.es.gov.br/digital/bitstream/123456789/3335/1/qualidadefisiologicadesementesdearoeira-oliveira.pdf.

OZDEN, E.; ERMIS, S.; DEMIR, I. Seed priming increases germination and seedling quality in Antirrhinum, Dahlia, Impatiens, Salvia and Zinnia seeds. Journal of Ornamental Plants, v.7, n.3, p. 171-176, 2017. http://jornamental.iaurasht.ac.ir/article_532996.html.

RATAJCZAK, E.; MAŁECKA, A.; CIERESZKO, I.; STASZAK, A.M. Mitochondria are important determinants of the aging of seeds. International Journal of Molecular Sciences, v.20, n.7, p.1-12, 2019. https://www.mdpi.com/1422-0067/20/7/1568.

SMITH, H.M.; SAMACH, A. Constraints to obtaining consistent annual yields in perennial tree crops. I: Heavy fruit load dominates over vegetative growth. Plant Science, v.207, p.158-167, 2013. https://doi.org/10.1016/j.plantsci.2013.02.014.

TEÓFILO, E.M.; SILVA, S.O.; BEZERRA, A.M.E.; MEDEIROS FILHO, S.; SILVA, F.D.B. Qualidade fisiológica de sementes de aroeira (Myracrodruon urundeuva Allemão) em função do tipo de embalagem, ambiente e tempo de armazenamento. Ciência Agronômica, v.35, p.371-376, 2004. http://www.ccarevista.ufc.br/site/down.php?arq=12rca35-2.pdf.

YUNIARTI, N.; KURNIATY, R.; SYAMSUWIDA, D. Study on priming methods to enhance the viability and vigor of trema (Trema orientalis Linn. Blume) seeds. Indonesian Journal of Forestry Research, v.6, n.1, p.69-83, 2019. https://doi.org/10.20886/ijfr.2019.6.1.69-83. use, distribution, and reproduction in any medium, provided the original work is properly cited. 